\title{
From LiveJournal with Love: A Comparative Analysis of Russia's Domestic and International Disinformation Campaigns
}

\author{
by J.J. Sylvia IV \\ Fitchburg State University
}

\begin{abstract}
This article compares and contrasts the use of disinformation by the Russian government domestically and internationally, with a particular emphasis on the role of the blogging platform LiveJournal in shaping these practices. The case study draws on sociopolitical and sociotechnical frameworks, tracing the key historical, social, technical, and legal characteristics that have led to Russia's successful use of disinformation and computational propaganda. This analysis demonstrates that LiveJournal played a key role in the pattern of disinformation deployed first against Russian citizens and then expanded internationally. In understanding this success, Russia has been able to transform its own domestic legal frameworks in order to prevent both citizens and outsiders from leveraging similar tactics within the country. By better understanding the role of LiveJournal in this history, it is possible to develop a deeper understanding of current active measures in Russia's information warfare.
\end{abstract}

Keywords: disinformation, Russia, LiveJournal, information warfare, computational propaganda, social media

On January 23, 2020, the Doomsday Clock was set to 100 seconds from midnight, the closest it has ever been to indicating the destruction of our world. The clock was created in 1947 and set at 7 minutes to midnight, serving as metaphor to help assess the danger of nuclear warfare, primarily with the Soviet Union. The 1991 setting of the clock at 17 minutes marks the furthest from midnight the clock has ever been. Over the years, the of this risk analysis for world destruction has grown to include other dangers, with climate change first being featured prominently in the 2007 assessment. In 2015, the assessment begins to take into account the new technological challenges of cyber attacks and artificial intelligence. By 2020, information warfare is described as a multiplier that increases the threat from both nuclear and climate catastrophe. The 2019 Bulletin of the Atomic Scientists argues that in our current environment "communication inflames passions rather than informing reason," and "threatens to replace these pillars of logic and truth with fantasy and rage," (6). These uses, it argues, threaten the very cohesion of society. How have the risks from information warfare grown so rapidly between 2015 and 2020 ?

LiveJournal, or Zhivoy Zhurnal in Russia, plays a relatively under analyzed but prominent role in the rise of information warfare. It became so popular at its peak that its shortened name, ZheZhe, became synonymous with online blogging in general. The story of LiveJournal, though available through a variety of reports and stories that have been written 
about it, has remained relatively obscure. Yet, it plays an important role in the history of computational propaganda, disinformation, and the changes to media law in Russia. Better understanding the social, legal, and technical history of this platform sheds light on Russia's more recent political disinformation campaigns in countries such as Ukraine and the United States.

Vladimir Putin's rise to power was aided by a media campaign powered by Russian oligarchs (Sanovich, 2019; Gessen, 2014). Perhaps due to seeing the power of media in his own success, Putin worked to exert control over television, radio, and print media within Russia. However, this control did not extend to the internet in the same way, perhaps because by 2002, only about two percent of adult Russians were using the internet (Etling et al., 2010; Sanovich 2019). At the same time Putin was rising to the office of Prime Minister in 1999 and then President in 2000, Brad Fitzpatrick was busy building the platform LiveJournal.

On January 5, 2006, Fitzpatrick sold his companies Danga Interactive and LiveJournal to Six Apart, becoming their Chief Architect. In announcing the sale, Fitzpatrick explained that while he had received offers from several other companies to purchase the site, Six Apart was the first that seemed to understand and resonate with the goals he had for LiveJournal (Fitzpatrick, 2005). Additionally, he shared that while he enjoyed the technology and design side of his work, he hated the business operations aspect of it. A year and a half later in October 2006, SixApart announced a partnership with SUP, a Russian media company owned by oligarch Alexander Mamut. This agreement caused widespread concern in the blogging community. By this time, Russian activists such as Alexei Navalny and Oleg Kashin were using the service to publish uncensored editorials critical of the the Russian government, often expressing concerns that would not have been allowed on larger state-controlled media (Hoffman, 2017). Six Apart employees emphasized that this was a licensing agreement for support only, and that no journals or their content would be transferred to Russia, thus protecting their content and authors from potential investigation or censorship by Russian authorities (kimmi8, 2006).

Fitzpatrick posted his own defense of the partnership, focusing primarily on technological and monetary issues (Fitzpartick, 2006). First, he argued that this partnership would be important for increasing the speed of the site within Russia: "The service is still so slow, hosted entirely in the US. (latency of $260 \mathrm{~ms}$ * 20-30 requests in series.... not fast!)," (Fitzpatrick, 2006, para. 11). Perhaps more interesting is his attempt to debunk what he describes as conspiracy theories about Mamut and his Russian links:

Mamut, more than anything, likes to make money. He owns a bunch of stuff. Him investing in SUP is probably chump change. Why not do it? Sure, he's politically connected, so you can make the argument that investing in blogs is just a way to shut them down, but then how does he make money? Lay on the conspiracy theories, but I don't care... it doesn't make any sense. I believe Mamut at the end of the day wants to make money, not shut down blogging as a favor to the Kremlin. Because shutting down blogging is futile and he'd realize that. (Fitzpatrick, 2006, para. 10). 
However, this defense probably overemphasizes the financial importance of the deal and puts a much too simplistic interpretation on how Russia could influence the service. Unfortunately, much of this would only become clear in hindsight.

One year later, in 2007, SUP purchased LiveJournal outright from Six Apart, bringing to fruition the worst fears of many users and former employees. One of these former employees shared publicly that during a criminal investigation in the U.S. that involved a LiveJournal user, code had been inserted into the site that allowed IP addresses to be tracked and notifications generated when certain users were accessing the site (insomnia, 2007). Concerns were raised about the possibility of a chilling effect on Russian bloggers and the potential for Russian government officials to access private materials and tracking code. By 2007, LiveJournal had just under six million Cyrillic users and was being used by $44 \%$ of Russian bloggers (Greenall, 2008). Many users felt acutely betrayed by this sale because it had been so clear how concerned they were about even a mere licensing agreement with SUP the previous year.

While the service's popularity declined in the U.S., it expanded significantly in Russia and was leveraged by politicians and activists (Hoffman, 2017). SUP initially continued to run LiveJournal out of its home in California, which afforded Russian bloggers some level of protection from Russian government requests for their data, as it was within U.S. jurisdiction. This protection was incredibly valuable because the Russian government was jailing citizens for their actions on other social networking sites during this period (Nossik, 2016). However, SUP unexpectedly moved its LiveJournal servers to Russia shortly after the 2016 U.S. Presidential election, leading to a crackdown on Russian bloggers and, virtually overnight, altering the legal protections of one of the most popular open platforms available to Russians and facilitating the prosecution and jailing of these bloggers.

The changes to LiveJournal were drastic and swift. Hoffman (2017) has analyzed the importance of this change in jurisdiction. Perhaps most significantly, LiveJournal could now be compelled by the Russian government to hand over any data that was requested due to the change in server location. The terms of service for the site were amended to reclassify every account that had over 3,000 viewers as a "media outlet," a shift that would make the writer subject to existing strict Russian censorship and prosecution laws. Some bloggers were subsequently jailed for the content of their writing, including Aleksei Kungurov, who was sentenced to two years in a Russian penal colony, which are widely known for their inhumane conditions (Kapustina, 2013). The changes to Russia's policy and approach to LiveJournal seemed to move slowly at first, with many downplaying concerns about these changes along the way. However, in 2016, these incremental movements coalesced into major and swift changes happening all at once. In many ways, the story of LiveJournal mirrors the Russian approach to the internet writ large. With this brief history in mind, the following sections offer a comparative analysis of Russia's national disinformation campaigns on LiveJournal and their international disinformation campaigns on Facebook, Instagram, Twitter, and other social media platforms. 


\section{Growing Concern over Social Media-Driven Protests}

The use of digital and social media for the creation and dissemination of disinformation has been widely explored in communication and media studies. Kathleen Hall Jamieson (2018) argues that Russian trolls and hackers helped elect Donald Trump to the United States presidency, while Sergey Sanovich (2019) has argued the domestic Russian disinformation campaigns using Twitter bots grew out of a longer history of television, radio, and print propaganda efforts. However, these analyses have not adequately addressed how the history of domestic Russian disinformation online compares to their more recent disinformation efforts in the United States. One of the primary challenges of researching contemporary disinformation practices is the speed with which new instances occur. Identifying, collecting, analyzing, reporting, and publishing the results of these efforts takes significant effort and time. These efforts are in themselves extremely valuable, but a sociotechnical approach (Marwick and Lewis, 2017; Marwick, 2018) that curates and analyzes this work at scale can shed new light both on how disinformation practices have developed historically and what new developments may be forthcoming.

Because Russia allowed political dissent and critique to grow along with the adoption of the internet among Russian citizens, many assumed it would not be possible for the Russian government to revoke these freedoms. As late as 2012, various scholars and experts argued that it seemed unlikely Russia would filter or censor the internet because of the political and business costs of doing so (Greenall, 2012). However, by this point, the Russian government was already keenly aware of the potential disruptive power of social media, with plans underway to wield it both defensively and offensively. Keir Giles (2016) has argued that Russia's shortcomings with their media influence during the Chechen wars of 1994-6 likely made clear that the nascent tools of the internet would reshape the the strategies for information warfare. Russian citizens sided with both foreign and domestic media that portrayed the "Chechen cause as one of justified resistance to Russian aggression," (Craik, 2019, p. 10). Even if actions were not being taken to limit speech on the internet, its threat was understood. "At parliamentary hearings in late 1996 entitled 'Russia and the Internet: The Choice of a Future,' a senior information security official characterized the internet as a whole as a threat to Russian national security," (Giles, 2016, p. 37). In 2000, the 'Information Security Doctrine of the Russian Federation' document, which was created by the Boris Yeltsin administration and signed by Vladimir Putin, demonstrated concern for foreign interference within Russia's informational spheres (Liñan, 2009; Craik, 2019).

It was not until 2008 that it would become clear to the international community that Russia had been taking action in regards to building infrastructure for informational warfare. A slew of cyber attacks accompanied Russia's invasion of Georgia in August of that year, disrupting networks and communication across the country (Connell and Vogler, 2017). Although Georgia's limited internet infrastructure meant that this cyber attack yielded relatively minor results, the success likely fueled increased Russian focus and efforts in the development of 
informational warfare tools (Connell and Vogler, 2017; Giles, 2016). Russia made significant use of traditional mass media tools such as television and newspapers, which had already been under state control for some time. Russia also differentiated its messaging for its domestic and international audiences. International messages focused on logical and legal arguments, while domestic messages featured emotional humanitarian issues (Rogoża and Dubas, 2008).

This seems to also mark a turning point in early use of explicit internet-based propaganda tactics. These tactics included "discussions on internet forums and circulating jokes about Georgia online, etc.," (Rogoża and Dubas, 2008, p. 4). The campaign in Georgia demonstrates the use of sophisticated online messaging to support Russian political operations quite early, and significantly, before protestors were using them as part of the Arab Spring movement. The use of jokes is also significant, because this focus on humor will become a major part of Russia's later strategy in other disinformation campaigns, especially those aimed at the United States. These media efforts stand out as major successes for Russia compared to their relative lack of sophistication in media messaging some 20 years earlier during the Chechen wars. Exactly how successful Russia's media efforts were in the Georgian conflict have been contested. Analysis in the wake of the event argued that while Russia had a military victory, it lost the media battle (Morozov, 2009; Halpin and Boyes, 2008). Even these critiques, though, pointed to significant achievements for the Russian media, noting that Vladimir Putin "made it clear to the world that Georgia had been the aggressor and that his soldiers were intervening to stop 'genocide'," and that "the picture of the Georgian President cowering from a Russian helicopter said it all," (Halpin and Boyes, 2008, para. 12 and 15). While Russia's efforts were likely more successful domestically than internationally in this media campaign, such efforts still made an impact internationally, with a particular nod to the rhetorical skill of Vladimir Putin.

International events were also influencing these concerns over the impact of internetbased tools. Giles (2016) argues that the Arab Spring movement that began in 2010 only reinforced Russian concerns about the use of the social media by the West to interfere with foreign governments and advocate regime change. For example, General Makhmut Gareyev, President of the Academy of Military Sciences argued that:

Internet networks were implanted in Egypt, Tunisia and Libya over a two-year period. It started with systematic training for communication checks, without direct calls for unlawful actions. At the right moment, a centralized order was issued across all networks for people to take to the streets. (Interfax news agency, March 26, 2011, as cited in Giles, 2016, 42)

Further, the failure of these governments to prevent the distribution of messages was attributed in 2014 to their not owning or controlling the servers on which these social networks were hosted (Giles, 2016). This critique stands out particularly because it comes after LiveJournal was purchased by a Russia-based company and only two years before legislation was passed required companies host information on Russian citizens on servers physically located in the country. 
In the midst of the Arab Spring movement, protests also began to erupt in Russia. Allegations of voter fraud in the December 4, 2011 Russian election spread across social media igniting "one of the biggest protest movements in post-Soviet Russia," (Klyueva, 2016, 4666), bringing together protestors throughout the month of December, possibly numbering as high as 120,000 people at a single demonstration. Although multiple social networks, including Facebook, played a role in these protests, LiveJournal hosted much of the commentary and planning. In 2012, an estimated $93 \%$ of active Russian election-related blogs were hosted on the LiveJournal platform (Greenall, 2012).

This string of events puts into context the growing distrust and unease with which Russian government officials viewed the internet and emerging social media platforms. Although they had been successful in disrupting networks during their own military maneuvers in Georgia, it was becoming increasingly clear that activists were leveraging these tools, many of which were hosted in other parts of the world, in order to create large protests that in some cases were able to topple regimes. The early success of such movements, however, marks a turning point at which the Russian government began to intervene in social media more actively and with more long term commitment (Klyueva, 2016). Popular reporting at the time begin to frame social media as a liberating tool of democracy, with the predominant sentiment being that countries that had not filtered or blocked access to the internet very early on would not be able to at this point because of the economic and political costs such a move would entail. Yet, Russia's next steps would demonstrate that these analyses were not entirely correct.

\section{The Shifting Legal Landscape in Russia}

Building on the success of the media campaign related to their military actions in Georgia, Russia begins taking significant steps to build up their internet-based capabilities. Despite significant cuts in other areas, the 2009 Russian budget increased spending on propaganda by $33 \%$, moving it to 1.4 billion USD, including an increase of $75 \%$ for online media (Morozov, 2009). At about the same time, the Russian government begin to increase its presence in online media with a focus on blogging in particular. Russian President Dmitry Medvedev launched a video blog on LiveJournal, which would continue to be updated through 2014 (Medvedev, 2014). This material continues to express the concerns of Russian government officials about the regulation of the internet. In an April 22, 2009 post that drew over 4000 comments, Medvedev argues that the United States should not be able set all of the rules for the internet, and that there should instead be an international effort to create rules that would help prevent unlawful activity (Hodge, 2009). A series of public lectures on Kremlin's School of Bloggers is also launched in 2009, with a May 14th lecture by Alexei Chadaev, billed as follows:

...a well-known political scientist, blogger and public figure, candidate of cultural science, associate professor of the Russian State Humanitarian University, member of the Public Chamber of the Russian Federation, editor-in-chief of the portal "Free World. 
Liberty", author of the book "Putin. His Ideology", director of the Kremlin School of Bloggers. ("Информационная работа в блогах," 2009)

A week after the lecture, on May 21, 2009, a video about the Kremlin School of Bloggers was posted to the YouTube account kgblogging. Titled, "Battle for History" the description explains the video as: "Member of the Public Chamber, Associate Professor of RGGU Alexei Chadaev about the Commission under the President of Russia to counteract the falsification of history," (kgblogging, 2009). The video features Chadaev explaining that the Commission was created to combat the falsification of history. Although the majority of the video features Chadaev speaking directly to the camera, there is footage of other Russian politicians edited in, along with popular music such as Pink Floyd's "The Happiest Days of Our Lives."

As of 2020, the video has received only just over 1,000 views. As an individual piece of propaganda, such a video was likely a failure by almost any metric. However, its existence is important as it puts a date on the creation of the early blogging efforts funded by the Russian government and makes clear that questions about truth will play a prominent role in these efforts. Thus, within only a few months, the Russian President joined LiveJournal, passed a surprisingly large budget for media propaganda, and launched a commission aimed at funding bloggers to promote pro-Russian ideology. These changes occur a little over one year after the Russian-based company SUP purchased LiveJournal and Russia's increasing ability to shape the media narrative was witnessed in the Georgian military conflict. This multi-pronged approach shows that by mid-2009, Russia was quite dedicated to moving into the realm of social media and blogging as a means of driving their propaganda and extending control of the larger media narrative. This early phase marked an effort to overcome opposition messages through the Russian government's creation of its own counter-narrative materials.

This is where clear differences begin to emerge in Russia's approaches to domestic and international information warfare. On the surface, it appears that the strategies are similar, as Russia works to create sophisticated rhetorical messages meant to compete with and counter the narratives of opposition factions both within Russia and internationally. By joining the messaging battle rather than initially suppressing or censoring it, Russia led many analysts to believe that free speech would continue to play a prominent role on the internet, even within Russia. But a gradual push to shift communication laws within Russia would eventually allow it to distinguish these approaches.

The changes began with a reorganization of the agencies overusing communications within Russia. Daniil Turvosky (2015) explains that in 2008, Roskomnadzor was founded when it separated from the Federal Service for Supervision of Mass Media, Telecommunications, and Protections of Cultural Heritage. This new agency first drew attention from the media in 2009 when:

The head of the agency warned media sources that they were responsible for what is posted by readers in the "comments" or "forum" section of their websites. The 
official stated, "if the editorial board doesn't want any trouble with the regulatory authorities, they have to moderate their forums." If "extremist" comments posted by any reader are found on a media website, this could result in a warning from Roskomnadzor. Some websites closed their forums, while others hired special moderators to monitor their "comments" sections. (Turvosky, 2015, para. 14).

If an organization receives three warnings from Roskomnadzor it is shut down. By contrast, in the United States, media sources such as internet service providers and websites that allow user generated content have been explicitly protected since the 1996 Communications Decency Act. Section 230 of this Act establishes that "No provider or user of an interactive service shall be treated as the publisher or speaker of any information provided by another information content provider," (47 U.S. Code $\S 230$ ). These diverging approaches over whom to hold responsible for online content has drastic and rippling effects.

In the U.S., this has led to media providers largely determining for themselves what kind of content restrictions, if any, should be in place on a site-by-site basis. However, the 3-strike policy in Russia places the onus on the site itself, making it potentially responsible for the actions of millions of users. This leads to an environment of being overly restrictive in moderation as means of survival. This can be seen in many websites which simply eliminated their forum features rather than risk not fully complying with the new regulations.

In the wake of these changes in 2009, the Arab Spring protests in 2010, and the Russian election protests of 2011 only served to demonstrate exactly how citizens might leverage these new media in order to advocate for regime change and "reportedly solidified in the minds of the Kremlin that the internet posed a direct threat to government stability," (Connell and Vogel, 2017, 25). It also marks a point of divergence in which Russia's domestic policies shift toward changing laws to prevent dissension online, while their international agenda begins to blossom into a robust and sophisticated disinformation and hacking campaign. In other words, the domestic agenda relies on restricting information and speech so that only government approved messages are easily created within Russia, while the international agenda relies on increasing the flow of information in ways that are designed to confuse and disrupt. However, these disinformation practices were fine tuned within Russia first, before later being applied to both Ukraine and the U.S.

In 2012 Russia passed what came to be known as its Blacklist laws, despite online protests from majors websites like LiveJournal and Wikipedia voicing their concerns about such a law. Estimates are that between 2012 and 2015, this law was used to block approximately 52,000 webpages (Turvosky, 2015). Perhaps worse is the fact that often it was the originating IP address of the content that was blacklisted, blocking additional sites that were not actually included in the list. This process of banning IP addresses may have added an additional 100,000 "accidental" blocked webpages during this time frame (Turvosky, 2015). 
2013 featured the passing of the Gay Propaganda Law, which drew significant international criticism due to the perception that this law negatively impacted not only LGBTQ rights in Russia, but also the ability to advocate for them. The beginning of the Internet Research Agency (IRA), which was responsible for social media interference in the 2016 U.S. election, also appears to have gotten its start in 2013. Although it was officially registered on July 26, 2013 there are troll posts dating as early as May of that year (Nimmo and Toler, 2018). The IRA, which would come to be called the Troll Factory, was not widely known in the U.S. until it was indicted by the Robert Mueller investigation into Russian interference in the 2016 U.S. election. However, reporting on this operation emerged as early as September of 2013 in Russian media and was more widely reported in 2015 with several English-language exposes (Garmazhapova, 2013; Soshnikov 2015; Toler, 2015; Volcheck and Sindelar, 2015).

Further legal changes loomed, with 2014 including several major changes that have had far-reaching impacts. First, the "Bloggers Law," requires that all webpages, including individual bloggers, that have a daily readership of 3,000 or more must register with Roskomnadzor as media outlet, thus making it responsible for the accuracy of what it publishes (MacFarquhar, 2014). This also means that these bloggers can no longer retain anonymity in their posts. Another law, passed in 2014 but taking in effect in 2016, required that foreign ownership stakes in Russian media companies could not exceed $20 \%$, lowering this from the previously required $50 \%$ (Luhn, 2014). This particular change was meant to reduce foreign influence in domestic media, allowing Russia to maintain tighter control of information within the country. Additionally, a "Localization Law" required that companies collecting data on Russian citizens use databases and servers located within Russia ("The 'localisation' of Russian citizen's personal data," 2018). This law went into effect in 2016, with increasing penalties taking effect in 2017 for non-compliance. 2017 was the year that SUP finally migrated their servers from the U.S. to Russia.

In addition to these domestic changes, Russia also ramped up its international efforts in 2014. The IRA formed a special subdivision aimed at targeting the U.S. 2016 election, beginning with a trip to the U.S. by Anna Bogacheva and Aleskandra Krylova in order to gain cultural reconnaissance for the forthcoming social media campaign (116th Congress, 1st Session, Senate, Report 116-XX). Through all of these steps, Russia is taking actions to prevent the domestic use of the same tactics it begins to deploy internationally.

A new twist arose in 2015. Rather than an additional law being passed, Roskomnadzor "clarified" its position on already existing laws, stating that the sharing of memes that do not accurately depict public figures is illegal (Dewey, 2015). Additional restrictions have only continued to accrue. In 2018, the anonymous use of messaging apps was banned, and the messaging service Telegram withdrew its service from the country when it refused to share its encryption keys (Meyer, 2018). 2019 featured a slew of new legislation and technological experiments. Russia outlawed the spread of fake news or other material which shows disrespect for Russia, its authorities, or related symbols, such as its flag (Balmforth, 2019). Depending on the violation, it can be punishable by fines of fines up to 400,000 rubles or 15 days of jail. It also 
banned the sale of phones and other devices that do not include pre-installed Russian software ("Russia bans sale of gadgets without Russian-made software, 2019). The law takes effect in July 2020 and has raised concerns about the potential to include government spyware. Taken together, these changes are likely aimed at preventing new forms of communication that have helped drive more recent protests. Protests in Sudan made use of encrypted messagings apps such as What's App to coordinate a sophisticated international network that supported local protests and eventually led to a military coup that deposed Sudanese President Omar al-Bashir ("Sudan's Bashir," 2016; Quinlan, 2019). With its recent legislation, Russian efforts can be understood as working to stay ahead of new uses of media that have driven protests around the globe.

In late December of 2019, Russia also announced that it performed a test in which it essentially disconnected from the global internet, maintaining only a national intranet, though details of this test remain vague (Wakefield, 2019). From a sociotechnical perspective, the Russian government made clear moves to limit the agency of potential citizen protestors through its use of legislation to curtail the technical affordances of the internet and social media within the country. At the same time, it was developing its international approaches to disinformation in a way that aligned with the much broader technological and legal affordances of the internet in other countries.

\section{Comparative Analysis of Domestic and International Social Media Approaches}

Early work and assignments by the IRA seem to be fairly unsophisticated. While several news sites, forums, and social media platforms were targeted, LiveJournal played a prominent role as a target for these campaigns and even contained its own department within the IRA (Volcheck and Sindelar, 2015). LiveJournal likely proved to be a helpful training ground for developing effective trolling methods. Although LiveJournal was playing a much larger role in Russia's media landscape than in the U.S. by 2013, there were certainly still many users from the U.S., including most prominently the writer George R.R. Martin, who continued to use the service through 2018.

One early tactic that emerged out of this practice was the idea of creating conversations in forums that featured a villain. Murhat Burkhard, who worked for the IRA, describes the process this way:

We did it by dividing into teams of three. One of us would be the "villain," the person who disagrees with the forum and criticizes the authorities, in order to bring a feeling of authenticity to what we're doing. The other two enter into a debate with him — "No, you're not right; everything here is totally correct." One of them should provide some kind of graphic or image that fits the context, and the other has to post a link to some content that supports his argument. You see? Villain, picture, link. (Volchek and Sindelar, 2015) 
These efforts were aimed at forums such as local news sites for various cities in Russia. These tactics offer an early peek into what evolve into a sophisticated form of interference in the U.S. election of 2016. In this case, Russian trolls created groups that catered to both the right and left of the American ideological spectrum. For example, one Facebook Page might be set up to support the progressive Black Lives Matter movement, while another is aimed at the conservative reactionary movement, Blue Lives Matter, which supports police officers in the wake of the negative attention that the Black Lives Matter movement generated for those officers. This approach was pushed even further by using Facebook Events to schedule competing protests at the same time. For example, in 2016 the IRA was able to spend \$200 promoting two separate events that brought together followers of their "Heart of Texas" Page, which had an anti-Islam message, and followers of the "United Muslims for America" Page, which supported a pro-Islamic message (116th Congress, 1st Session, Senate, Report 116-XX). These overlapping protests generated a confrontation that was significant enough to be covered by local newspapers.

The focus on using some type of graphic or image in these early posts also developed into a larger strategy of posting memes in order to gain followers in the U.S. These memes were able to leverage complex nuances of U.S. culture, with imagery that generated impressive levels of engagement. The Facebook paid advertisements, for example, had a 9.2\% click-through-rate, which is significantly higher than the industry average of $0.9 \%$ (Author, 2019). Tactics developed and perfected on LiveJournal likely helped the IRA develop such engaging content. After SUP's purchase of LiveJournal in 2007, the Russian government had easier access to a large database of U.S. cultural content. But they also perfected a model of posting that was not exclusively political. This served two purposes - it made it more difficult to spot trolls because they posted about a wider variety of topics, but it also drove up engagement.

Reporting from 2015 shows how the IRA LiveJournal troll account "cotedo," operated by "Natalya Drozdova," was able to achieve this. As Toler (2015) explains, each day the IRA would send out technical briefings that explained what needed to be covered on that day. On February 28, 2015, the technical briefing asked for the IRA workers to argue that the death of Boris Nemtsov was not accidental, and likely involved Ukrainian officials. One of Natalya's posts from that day explicitly covered that topic. Yet, threaded in among that were other posts on nonpolitical topics:

Most of Natalya's posts are unremarkable, such as a post about Facebook removing the "feeling fat" status, a whole array of Fifty Shades of Grey parodies, and a post requesting advice after a bizarre conflict with a shopping mall janitor over bringing a baby carriage into the bathroom. (Toler, 2015, para 7)

This intermingling of political and non-political content also appears in the IRA's Facebook ads campaign in the U.S. The ad that generated the second highest number of shares, for example, featured a Black History Month fact about the potato chip being invented by George Crum (Author, 2019). Many of the other ads were focused specifically on humor, drawing on popular 
culture elements that ranged from Doctor Who to SpongeBob SquarePants. This content, along with additional non-paid, organic content, was designed to attract followers who could then be targeted with a well-timed political message at a kairotic moment (Soshnikov, 2015).

While Russian efforts targeting social media generated significant successes, other operations were also under way. Efforts were made to hack voting machines as well as email accounts of prominent politicians, which were sometimes leaked at strategic moments (DiResta et al., 2018). Further, Russia has begun investigating both subsea communication cables and communication satellites (Giles 2016). Such actions suggest research and preparation for targeting technical infrastructures in addition to its disinformation practices.

\section{Conclusion}

A sociotechnical analysis reveals that LiveJournal plays a central role in the history of Russia's approach to the internet and information warfare. Russian citizens leveraged LiveJournal and it became the first popular blogging platform in the country. It played a prominent role in facilitating protests in Russia, in much the same way as Twitter and other social media did during the Arab Spring protests. The Russian government's response to these events would inform their cultural, political, legal, and technological strategies both domestically and internationally. By joining the discussion on social media rather than initially outright blocking it, Russian officials were able to craft a complex cultural response that eventually blossomed into their disinformation campaign, first domestically, and then internationally. Legally and politically, LiveJournal was also at the center of jurisdiction disputes. Initially hosted in the U.S., it was bought by a Russian company and due to legal changes, the servers were eventually moved to Russia. These changes were at the core of a series of moves - still ongoing - in which Russia is slowly ensuring that is has access to and control of all digital media that is being used within the country.

This analysis also brings to the forefront the important role of social media in the political confrontations between democratic and authoritarian movements. While democratic activists were the first to leverage the power of social media, more authoritarian governments have now become thoroughly invested in using the tools for their own purposes, with some success in stymying and/or eroding democratic norms both domestically and internationally. Kerr (2018) has argued that information warfare approaches used by Russia have been adopted by other countries in the Former Soviet Union. Kerr's analysis also found that these approaches used a "relatively low level of static censorship paired with significant degrees of pro regime content production and manipulation," (3820). But legal changes implemented in 2018 and 2019 suggest that an emphasis on censorship is increasing, reaching beyond publicly shared information on social media and including encrypted private messaging. In light of its own success with disinformation abroad, Russia is taking increasing legal steps domestically to prevent similar

uses of information technology within its own borders. As it has learned from its own battle 
against LiveJournal, Russia continues to take note of democratic uses of technology elsewhere in the world, working to make sure these tools can not be used domestically.

This social and legal landscape within the realm of information warfare presents the challenge of how to prevent harmful uses of disinformation against one's own citizens without curtailing democratic and free speech principles. Debate has emerged in the U.S. over whether to modify or eliminate the protections of Section 230 of the Communication Decency Act (Laslo, 2019). Social media companies have taken some steps aimed specifically at trying to curtail election interference, with Facebook preventing foreign spending on any election advertisements and Twitter banning all political advertising (Conger, 2019). Others have called for increased information and media literacy, though the effectiveness of these strategies remain in doubt (boyd, 2018). However, these actions do not prevent the organic content and non-paid practices of computational propaganda and disinformation actors. What remains is a complicated informational warfare arms race that spans technical, social, and legal fronts. Analysis of the IRA's role in the 2016 U.S. election reveals that new tactics are already in development, such as enticing users to share more information about themselves by installing applications like FaceMusic (Author, 2019). This Facebook application appears entirely non-political, and allows users to have access to music they can play after agreeing to terms (likely without reading them) that allow the application creators to access and change all of their Facebook related data. Russian reporter Lyudmila Savchuk worked undercover in one of the Russian troll factories and was surprised that the exposure of these practices did not generate a greater level of concern, both within Russia and by foreign governments (Tlis, 2018). Further, she has argued that the West remains consistently behind the curve in Russian's information warfare practices, playing catch up by reacting to past actions rather than proactively addressing current active measures. By better understanding how the LiveJournal platform shaped Russian reactions and future approaches to information warfare, it may be easier to assess the current information landscape and develop deeper insight into active measures being taken by Russia and other governments around the world. These will be important questions as citizens of democracies wrestle with how to dial back inflamed passions, fantasies, and rage promoted by today's social media practices and work to push the hands of the Doomsday Clock further away from midnight.

\section{References}

47 U.S. Code \$ 230-Protection for private blocking and screening of offensive material. (n.d.). LII / Legal Information Institute. Retrieved January 22, 2020, from https:// www.law.cornell.edu/uscode/text/47/230

116th Congress, 1st Session Senate. (2019). Report of the Select Committee on Intelligence, United States Senate on Russian Active Measures Campaigns and Interference in the 2016 U.S. Election, Volume 2: Russia's Use of Social Media with Additional Views (No. 116-XX). 116th Congress. 
Author (2019).

Balmforth, T. (2019, March 18). Russia's Putin signs law banning fake news, insulting the state online. Reuters. https://www.reuters.com/article/us-russia-politics-fakenewsidUSKCN1QZ1TZ

boyd, danah. (2018, March 16). You Think You Want Media Literacy... Do You? Medium. https:// points.datasociety.net/you-think-you-want-media-literacy-do-you-7cad6af18ec2

Conger, K. (2019, October 30). Twitter Will Ban All Political Ads, C.E.O. Jack Dorsey Says. The New York Times. https://www.nytimes.com/2019/10/30/technology/twitter-political-adsban.html

Connell, M., \& Vogler, S. (2017). Russia's Approach to Cyber Warfare. CNA Analysis \& Solutions.

Craik, P. B. (2019). The Weaponization of Postmodernism: Russia's New Way with Europe (No. 146; "Europe in Question" Discussion Paper Series). London School of Economics and Political Science.

Dewey, C. (2015, April 10). Russia just made a ton of Internet memes illegal. Washington Post. https://www.washingtonpost.com/news/the-intersect/wp/2015/04/10/russia-just-made-aton-of-internet-memes-illegal/

DiResta, R., Shaffer, D. K., Ruppel, B., Matney, R., Fox, R., Albright, D. J., Johnson, B., \& Research, C. (2018). The Tactics \& Tropes of the Internet Research Agency. 101.

Etling, B., Alexanyan, K., Kelly, J., Farris, R., Palfrey, J., \& Gasser, U. (2010). Public Discourse in the Russian Blogosphere: Mapping RuNet Politics and Mobilization (No. 2010-11; The Berkman Center for Internet \& Society Research Publication). Harvard University.

Fitzpatrick, B. (2005, January 5). Big news... Six Apart and LiveJournal! LiveJournal. https:// news.livejournal.com/82926.html

Fitzpatrick, B. (2006, November 1). LiveJournal, SUP, Russia links—Brad's life-LiveJournal. LiveJournal. https://brad.livejournal.com/2261770.html

Garmazhapova, A. (2013, September 19). Где живут тролли. Как работают интернетпровокаторы в Санкт-Петербурге и кто ими заправляет. Novayagazeta.Ru. https:// novayagazeta.ru/articles/2013/09/09/56265-gde-zhivut-trolli-kak-rabotayut-internetprovokatory-v-sankt-peterburge-i-kto-imi-zapravlyaet

Gessen, M. (2014). The man without a face: The unlikely rise of Vladimir Putin. 
Giles, K. (2016). Handbook of Russian Information Warfare [Fellowship Monograph]. Research Division, NATO Defense College.

Greenall, R. (2012, March 2). LiveJournal: Russia's unlikely internet giant. BBC News. https:// www.bbc.com/news/magazine-17177053

Halpin, T., \& Boyes, R. (2008, August 13). Georgia loses the fight with Russia, but manages to win the PR war. Times Online. https://web.archive.org/web/20090514064928/http:// www.timesonline.co.uk/tol/news/world/europe/article4518254.ece

Hodge, N. (2009, April 28). Kremlin 2.0: Russian Prez Discovers Social Media. Wired. https:// www.wired.com/2009/04/kremlin-20-russian-prez-discovers-social-media/

Hoffman, J. (2017). Whatever Happened to LiveJournal? The History of the Web. https:// thehistoryoftheweb.com/postscript/whatever-happened-livejournal/

insomnia. (2007, December 4). My thoughts on the sale-Again-Of LiveJournal.: InsomniaLiveJournal. LiveJournal. https://insomnia.livejournal.com/774132.html

Jamieson, K. H. (2018). Cyberwar: How Russian hackers and trolls helped elect a president ; what we don't, can't, and do know. Oxford University Press.

Johansson, E., \& Nygren, G. (2014). Russian Journalists and Social Media: Updated Traditions and New Challenges. Central European Journal of Communication, 7(2), 273-290.

Kapustina, O. (2013, February 10). Everyday life in a Russian penal colony | Europe| News and current affairs from around the continent | DW | 02.10.2013. Deutsche Welle. https:// www.dw.com/en/everyday-life-in-a-russian-penal-colony/a-17131773

Kerr, J. A. (2018). Information, Security, and Authoritarian Stability: Internet Policy Diffusion and Coordination in the Former Soviet Region. International Journal of Communication, $12,3814-3834$.

kgblogging. (2009, Мау 21). Битва за историю. https:/www.youtube.com/watch? $\mathrm{v}=\mathrm{ii} 73 \mathrm{AjOG} 9 \mathrm{qc}$

kimmi8. (2006, October 18). LJ and SUP: lj_biz_LiveJournal. LiveJournal. https://1jbiz.livejournal.com/239637.html

Klyueva, A. (2016). Taming Online Political Engagement in Russia: Disempowered Publics, Empowered State, and Challenges of the Fully Functioning Society. International Journal of Communication, 10, 4661-4680. 
Laslo, M. (2019, August 13). The Fight Over Section 230-And the Internet as We Know It. Wired. https://www.wired.com/story/fight-over-section-230-internet-as-we-know-it/

Lian, M. V. (2009). Putin's Propaganda Legacy. Post-Soviet Affairs, 25(2), 137-159. https:// doi.org/10.2747/1060-586X.24.2.137

Luhn, A. (2014, September 26). Russia tightens limit on foreign ownership of media. The Guardian. https://www.theguardian.com/world/2014/sep/26/russia-limit-foreignownership-media

MacFarquhar, N. (2014, May 6). Russia Quietly Tightens Reins on Web With 'Bloggers Law.' The New York Times. https://www.nytimes.com/2014/05/07/world/europe/russia-quietlytightens-reins-on-web-with-bloggers-law.html

Marwick, A. E. (2018). Why Do People Share Fake News? A Sociotechnical Model of Media Effects. Georgetown Law Technology Review, 2(2), 474-512.

Marwick, A., \& Lewis, R. (2019). Media Manipulation and Disinformation. Data \& Society. https://datasociety.net/pubs/oh/

DataAndSociety_MediaManipulationAndDisinformationOnline.pdf

Mecklin, J. (Ed.). (2019). 2019 Doomsday Clock Statement (Bulletin of the Atomic Scientists). https://media.thebulletin.org/wp-content/uploads/2019/01/2019-Clock-Statement-PressPrint-Version.pdf

Medvedev, D. (n.d.). Блог Дмитрия Медведева-ЖЖ. LiveJournal. Retrieved January 22, 2020, from https://blog-medvedev.livejournal.com/

Meyer, D. (2018, November 6). Russia: Now everyone who uses a messaging app must be identifiable. ZDNet. https://www.zdnet.com/article/russia-now-everyone-who-uses-amessaging-app-must-be-identifiable/

Morozov, E. (2009, May 9). The Kremlin's quest for Pravda 2.0. ForeignPolicy.Com. https:// web.archive.org/web/20090515133248/http://neteffect.foreignpolicy.com/posts/ 2009/05/09/kremlins_quest_for_pravda_20

Nimmo, B., \& Toler, A. (2018, March 26). How They Did It: The Real Russian Journalists Who Exposed the Troll Factory in St. Petersburg. Global Investigative Journalism Network. https://gijn.org/2018/03/26/real-russian-journalists-exposed-troll-factory-st-petersburg/

Novak, E., Razzouk, R., \& Johnson, T. E. (2012). The educational use of social annotation tools in higher education: A literature review. The Internet and Higher Education, 15(1), 3949. https://doi.org/10.1016/j.iheduc.2011.09.002 
Quinlan, C. (2019, December 14). Omar al-Bashir, deposed president of Sudan, has been sentenced to 2 years in a reform facility. Vox. https://www.vox.com/world/ 2019/12/14/21021847/omar-al-bashir-sudan-sentenced-corruption-icc

Rogoża, J., \& Dubas, A. (2008). Russian propaganda war: Media as a long- and short-range weapon (Commentary). Centre for Eastern Studies.

Russia bans smartphones without local software. (2019, November 21). BBC News. https:// www.bbc.com/news/world-europe-50507849

Sergey, S. (2019). Russia: The Origins of Digital Misinformation. In Computational Propaganda: Political Parties, Politicians, and Political Manipulation on Social Media (pp. 21-40). Oxford University Press.

Soshnikov, Andrey. (2015, March 11). Столица политического троллинга. MR7.Ru. https:// mr-7.ru/articles/112478/

Sudan's Bashir: I won't be toppled by WhatsApp. (2016, December 13). News24. https:// www.news24.com/Africa/News/sudans-bashir-i-wont-be-toppled-by-whatsapp-20161213

The "localisation" of Russian citizens 'personal data. (2018, September 5). KPMG Belgium. https:/home.kpmg/be/en/home/insights/2018/09/the-localisation-of-russian-citizenspersonal-data.html

Tlis, F. (2018, October 17). Working in Russian Troll Factory Pushed Reporter to 'Edge of Insanity. ' POLYGRAPH.Info. https://www.polygraph.info/a/russian-troll-factoryexposed/29549344.html

Toler, A. (2015, March 14). Inside the Kremlin Troll Army Machine: Templates, Guidelines, and Paid Posts. Global Voices. https://globalvoices.org/2015/03/14/russia-kremlin-troll-armyexamples/

Turovsky, D. (2015, August 13). This is how Russian Internet censorship works: A journey into the belly of the beast that is the Kremlin's media watchdog. Meduza. https://meduza.io/ en/feature/2015/08/13/this-is-how-russian-internet-censorship-works

Volchek, D., \& Sindelar, D. (2015, March 25). One Professional Russian Troll Tells All. RadioFreeEurope RadioLiberty. https:/www.rferl.org/amp/how-to-guide-russian-trollingtrolls/26919999.html

Wakefield, J. (2019, December 24). Russia “successfully tests" its unplugged internet. $B B C$ News. https://www.bbc.com/news/technology-50902496 
Информационная работа в блогах: Цели и задачи. Взгляд из 2009 года. Анонс лекции Алексея Чадаева. (9 C.E., May 13). Liberty.Ru. https://web.archive.org/web/ 20090601012624/http://liberty.ru/events/Informacionnaya-rabota-v-blogah-celi-izadachi.-Vzglyad-iz-2009-goda.-Anons-lekcii-Alekseya-CHadaeva 